\title{
Lotic biofilm community structure and pesticide tolerance along a contamination gradient in a vineyard area
}

\author{
Ursula Dorigo ${ }^{1}$, Christophe Leboulanger ${ }^{2,3}$, Annette Bérard ${ }^{1}$, Agnès Bouchez ${ }^{2}$, \\ Jean-François Humbert ${ }^{2,4}$, Bernard Montuelle ${ }^{1, *}$ \\ ${ }^{1}$ CEMAGREF, UR Qualité des Eaux, 3 Quai Chauveau CP, 69336 Lyon Cedex 09, France \\ ${ }^{2}$ INRA UMR CARRTEL, Laboratoire de Microbiologie Aquatique, BP 511, 74203 Thonon Cedex, France \\ ${ }^{3}$ IRD UR 167 Cyroco, UMR 5119, CNRS-Université Montpellier II, cc 093, 34095 Montpellier Cedex 05, France \\ ${ }^{4}$ Institut Pasteur - CNRS URA 2172, Unité des Cyanobactéries, 28 rue du Dr. Roux, 75724 Paris Cedex 15, France
}

\begin{abstract}
We investigated the environmental impact of diffuse pesticide pollution on natural river biofilms in the River Morcille, France, during 2 seasons in pristine and contaminated stations. Prokaryotic and eukaryotic community compositions were assessed by denaturing gradient gel electrophoresis, while microalgal community composition was determined by high pressure liquid chromatography pigment analysis. The sensitivity of microphytobenthos to the herbicide Diuron was investigated in the laboratory by short-term photosynthesis inhibition assays. Spatial changes in prokaryotic and eukaryotic species compositions were found in spring and in winter. Community structures were significantly different between contaminated areas and those that were uncontaminated or less contaminated. Associated changes in biodiversity were not found. Community tolerance towards Diuron (based on EC50 values for photosynthesis) was significantly lower in upstream than in downstream photoautotrophic organisms. Pesticide concentration increased along the downstream gradient. These results strongly suggest contamination-driven changes in biofilm community structure and in the tolerance of the photoautotrophic community, confirming the Pollution-Induced Community Tolerance (PICT) hypothesis.
\end{abstract}

KEY WORDS: Biofilms $\cdot$ Community structure $\cdot$ Community tolerance $\cdot$ Pesticides $\cdot$ Vineyard area Resale or republication not permitted without written consent of the publisher

\section{INTRODUCTION}

A multitude of anthropogenic sources, such as industrial, domestic and agricultural wastes, results in freshwater eutrophication and contamination through point- or diffuse pollution. This may affect and degrade (temporarily or permanently) aquatic ecosystem biodiversity and functioning. Agricultural landscapes, such as vineyards or orchards, are treated with pesticides most of the time and generate water pollution through run-off, leaching and diffusion (Landry et al. 2004, Vu et al. 2006). The control and reduction of diffuse pollution is a complex task (especially for water-soluble substances) and the ecological side effects of contamination in rivers may be variable because of the diversity of current pesticides (herbicides, fungicides, insecticides, etc.) (Benoit et al. 2005). In low-order streams (Strahler order $<3$ or 4 ) that drain rural watersheds, the impact of pesticides on non-target aquatic organisms can be particularly severe (Dorigo et al. 2003, Weston et al. 2004) because of the low dilution potential. In such systems, trophic webs are generally reduced and most microorganisms live on submerged substrata (such as biofilms or periphyton). Biofilms comprise a complex assemblage of taxonomic and/or functional groups embedded in a polysaccharidic and proteic matrix. Prokaryotic (bacteria) and eukaryotic (mostly microalgae, but also fungi) organisms strongly interact and are responsible for most of the energy input through primary production. They contribute signifi- 
cantly to nutrient cycling in such environments (Battin et al. 2003). The development, structure and functions of biofilms are well studied, as are the effects of natural environmental factors such as light, flow and grazing pressure (Sabater et al. 2002, Romani et al. 2004). Impairment of periphyton by anthropogenic compounds is not well understood.

In streams running through agricultural areas, mixtures of chemicals derived from agricultural activity may directly or indirectly affect biofilm community structure and function (Boivin et al. 2006). These mixtures are expected to disturb major biogeochemical cycles (carbon, nitrogen, phosphorus), self purification capacity and trophic web configuration (Brock et al. 2004). A variety of methods exists to detect the impact of pesticides on functional and structural parameters; periphyton could be considered as an early warning indicator system for contamination detection (reviewed by Sabater et al. 2007). There are more data available for periphytic microalgal communities (Guasch et al. 1998, Dorigo \& Leboulanger 2001, Barranguet et al. 2002, Schmitt-Jansen \& Altenburger 2005) than for periphytic bacterial communities (Pesce et al. 2006). To our knowledge, this is the first in situ comprehensive study on both microalgal and bacterial components of biofilm communities.

In our field study we clarified the impact of diffuse pesticide pollution on natural biofilms along a small river that drains water from a vineyard watershed. This stream is subjected to increased pesticide pressure in the downstream direction. Natural biofilms were grown in situ on artificial glass substrata during spring 2004 and winter 2005 in 1 pristine and 2 impacted areas. The compositions and structures of prokaryotic and eukaryotic communities were assessed by PCRDGGE on 16S and 18S rRNA gene fragments, respectively, with parallel pigment analyses by HPLC.

To apply the Pollution-Induced Community Tolerance (PICT) concept, we performed short-term laboratory experiments to assess natural tolerance of the photoautotrophic communities to Diuron, which is one of the toxins found in this river. The PICT concept assumes that communities exposed to contaminants become tolerant to them (by adaptation or species changes, etc.). Accordingly in laboratory toxicity assays, exposed communities should be characterized by higher EC50 values than reference communities. This concept allows assessment at a community level of ecological impact or, conversely, ecological recovery.

\section{MATERIALS AND METHODS}

Study sites. The study was carried out on the River Morcille $\left(46.150^{\circ} \mathrm{N}, 4.600^{\circ} \mathrm{E}\right.$, Beaujolais vineyard area;
Table 1. Composition $\left(\mathrm{km}^{2}\right)$ of the catchment area and percentage of total area occupied by vineyards in St. Joseph $(\mathrm{J})$, Versauds (V) and St. Ennemond (E). (Modified from Montuelle et al. 2006)

\begin{tabular}{|lccc|}
\hline & $\mathrm{J}$ & $\mathrm{V}$ & $\mathrm{E}$ \\
\hline Sparsely urbanised area & 0 & 0 & 0.28 \\
Vineyard & 0.2 & 2.27 & 6.20 \\
Grassland & 0.20 & 0.59 & 1.59 \\
Multi culture system & 0.56 & 0.56 & 0.59 \\
Deciduous forest & 0.13 & 0.13 & 0.12 \\
Coniferous forest & 0.09 & 0.09 & 0.09 \\
Mixed forest & 0.63 & 0.64 & 0.63 \\
Dense vegetation & 0.02 & 0.02 & 0.02 \\
Total surface & 1.82 & 4.28 & 9.52 \\
\% occupied by vineyards & 11 & 53 & 65 \\
\hline
\end{tabular}

the river is a tributary of the River Ardière, which is a tributary of the River Saône). The River Morcille is 7 $\mathrm{km}$ long and relatively shallow (Strahler order 1). Its watershed $\left(8.5 \mathrm{~km}^{2}\right)$ is underlain by granite, leading to the formation of soft water. The river bottom is mainly composed of pebbles and sand, with a minor coverage of fine sediment. Located in an intensive wine production region $(55 \%$ of the catchment area is occupied by vineyards; see Table 1 for details), the river is subject to pesticide run-off. The traditional application of pesticides to the vineyards (from end of March to end of July) contributes to the downstream contamination gradient along the river down to its mouth. Three longitudinally arranged sampling areas with different levels of pesticide contamination were chosen, St. Joseph $(J)$, Versauds (V) and St. Ennemond (E), listed from upto downstream (Fig. 1). As shown in Table 1, the percentage contribution of vineyards to total catchment area increases in the sequence $\mathrm{J}>\mathrm{V}>\mathrm{E}$. Grassland, multi-culture systems and forest are present in each of the areas. Sparce urban areas occur only in Area E.

Sampling procedure. In order to reduce heterogeneity that occurs among natural substrata, periphyton was collected on artificial substrata (Cattaneo et al. 1997, Sabater et al. 1998). We controlled the colonization surface of the substratum and the maturation level of the biofilm. We used small frosted glass discs $\left(1.5 \mathrm{~cm}^{2}\right.$ surface area) glued to Plexiglas ${ }^{\mathrm{TM}}$ plates with silicon sealant (Dorigo \& Leboulanger 2001). In each of the 3 sampling areas, 3 Plexiglas plates were placed in the center of the stream, horizontally fixed to the riverbed. The plates were exposed to similar light levels (measured with a TESTO 545 luxmeter) and water currents (measured with a FlowMate 2000 flowmeter). After 2 mo of biofilm colonization, plates from each of the sampling areas were removed, placed within individual plastic bags filled with river water and transported in cool-boxes within $2 \mathrm{~h}$ to the laboratory. For 


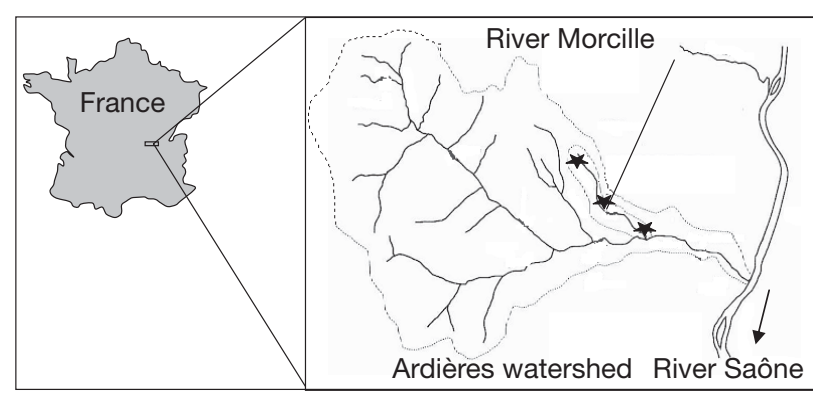

Fig. 1. Catchment area of the River Morcille, France, and sampling locations (stars)

HPLC and DGGE analyses, glass substrata were immediately frozen and stored at $-80^{\circ} \mathrm{C}$ for further processing. The whole sampling strategy was performed in spring (mid-April to mid-June 2004) and in winter (February to March 2005) for 2 reasons. Firstly, the seasons differ in the quality and quantity of pesticides applied to the vineyards (intensive in spring and theoretically 'calm' in winter; although there is no pesticide application in winter, leaching and runoff are still possible). Secondly, biofilm communities vary naturally in species composition by season (Sekar et al. 2004, Lyautey et al. 2005a), and the response of biofilms to contaminants may depend on community configuration (Bérard et al. 1999, Bérard \& Benninghoff 2001) and on seasonal variations in environmental conditions (e.g. light regime, water level, temperature, Guasch et al. 1997).

Water sampling and physico-chemical analyses. During 2 mo of biofilm colonization, physical parameters (current, depth, light intensity, temperature) were measured weekly at 10:00 h for each Plexiglas plate. At the same time, 21 water samples were collected in polyethylene bottles from each sampling area (J, V, E) for measurement of chemical parameters (including DOC, $\mathrm{NO}_{2}{ }^{-}, \mathrm{NO}_{3}{ }^{-}, \mathrm{NH}_{4}{ }^{+}$and $\mathrm{PO}_{4}{ }^{3-}$, conductivity, $\mathrm{pH}$ ) following standard procedures and protocols (AFNOR 1982). At the end of biofilm colonization, water samples for analysis of organic pesticides were collected in clean dark glass bottles at each sampling area. A total of 333 pesticides and degradation products were searched for (using standardized protocols) with a multidetection analysis system comprising gas (GC/MS) and liquid chromatography (HPLC/MS/MS). These chromatographic analyses were done by 'Laboratoire Départemental d'Analyses de la Drôme' (www.lda26. com/).

Periphyton DNA collection and extraction. In the laboratory, each biofilm sample was collected by scraping 6 glass discs taken from each Plexiglas plate (3 plates from the 3 Areas J, V, E) with a hard bristle tooth brush. Collected materials were suspended in $2 \mathrm{ml}$ aliquots of $0.2 \mu \mathrm{m}$ filtered water (from the respec- tive rivers) and kept at $-80^{\circ} \mathrm{C}$ until processing. Biofilm solutions were centrifuged at $14000 \times g$ for $30 \mathrm{~min}$ and the supernatant was discarded. Nucleic acid extraction was performed on biofilm pellets according to Massana et al. (1997), with some modifications. Briefly, pellets received $750 \mu \mathrm{l}$ of lysis buffer and were processed exactly as described in Dorigo et al. (2006). Purified DNA was precipitated and resuspended in $50 \mu$ of TE (10 mM Tris, $1 \mathrm{mM}$ EDTA, pH 8). The integrity of the total DNA was checked by agarose gel electrophoresis, and quantified by measuring absorbance at $260 \mathrm{~nm}$.

PCR amplification of $16 \mathrm{~S}$ and $18 \mathrm{~S}$ rRNA gene fragments. PCR amplification of the eukaryotic 18S rRNA gene fragment was performed with $60 \mathrm{ng}$ of template DNA and the primers Euk1Af and Euk516r-GC, producing a $560 \mathrm{bp}$ fragment. PCR amplification of the bacterial 16S rRNA gene fragment was done with $30 \mathrm{ng}$ of template DNA and the primers $341 \mathrm{f}$ with an attached GC-rich fragment and $907 \mathrm{rM}$, producing a 590 bp fragment. In both cases, PCR amplifications were performed on $50 \mu \mathrm{l}$ volumes containing a $10 \mathrm{X}$ Taq reaction buffer (Eurobio), $1.5 \mathrm{mM} \mathrm{MgCl}_{2}, 120 \mu \mathrm{M}$ of each deoxynucleotide, $1 \mu \mathrm{M}$ of each primer, bovine serum albumin (Sigma, $0.5 \mathrm{mg} \mathrm{ml}^{-1}$ final concentration), and 1.25 U Taq DNA polymerase (Eurobluetaq, Eurobio). All PCR reactions were performed using a Thermal Cycler T-Personal (Biometra). For each set of reactions, a negative control (in which the template was replaced by an equivalent volume of sterile deionized water) was included. PCR reactions for 16S rDNA and 18S rDNA amplification were carried out according to Schauer et al. (2000) and Diez et al. (2001b), respectively. The presence of PCR products of the correct size was confirmed by analyzing $4 \mu \mathrm{l}$ of product on an ethidium bromide-stained, $1.2 \%$ (w/vol) agarose gel in 1X TBE buffer (89 mM Tris base, $89 \mathrm{mM}$ boric acid, 2 mM EDTA, pH 8.0).

Denaturing gradient gel electrophoresis (DGGE) and data analysis. DGGE analysis was performed using a CBS-DGGE 2000 system (C.B.S. Scientific) on $0.75 \mathrm{~mm}$ thick $6 \%$ polyacrylamide gels (ratio of acrylamide to bisacrylamide was 37.5:1) submerged in $1 \mathrm{X}$ TAE buffer (40 mM Tris acetate $\mathrm{pH}$ 7.4, $20 \mathrm{mM}$ sodium acetate, $1 \mathrm{mM} \mathrm{Na}{ }_{2}$ EDTA). Urea and deionized formamide were used as denaturing agents, and the gel gradient varied from from $40 \%$ (top) to $80 \%$ (bottom) for PCR-amplified 16S rRNA gene fragments (Schauer et al. 2000, Dorigo et al. 2006), and from $40 \%$ (top) to $65 \%$ (bottom) for PCR-amplified 18S rRNA gene fragments (Díez et al. 2001a). In both cases, $40 \mu l$ of PCR products were loaded and run at a constant voltage of $100 \mathrm{~V}$ and at a temperature of $60^{\circ} \mathrm{C}$ for about $16 \mathrm{~h}$. Separated PCR products were stained for $45 \mathrm{~min}$ in the dark with SYBRGold (Molecular Probes), visualized 
on a UV transilluminator (Claravision), and photographed (Scion Corporation camera). Digital images of the gels were saved for further analysis using Microsoft Photo Editor software and processed as described by Dorigo et al. (2006). For each gel, a table was constructed (with samples as rows and DGGE bands as columns) by scoring 1 or 0 for the presence or absence, respectively, of a nucleic acid band at a given height in each lane. Matrices were used for multivariate correspondence analysis (an ordination procedure) using the ADE-4 software package.

Pigment analysis by high pressure liquid chromatography (HPLC). For each biofilm sample, one glass disc per Plexiglas ${ }^{\mathrm{TM}}$ plate was placed in a centrifuge tube (Corning) containing $4 \mathrm{ml}$ of methanol/0.5 M ammonium acetate $(98 / 2 \mathrm{v} / \mathrm{v})$ solution and sonicated with a $4 \mathrm{~mm}$ probe for $1 \mathrm{~min}$ at $180 \mathrm{~W}$ and at $50 \%$ activity (Vibracell, Bioblock Scientific 375W). After sonication, the tubes were centrifuged $(6000 \times g)$ for 6 min at $0^{\circ} \mathrm{C}$. The supernatant was collected and purified by filtering through a $0.2 \mu \mathrm{m}$ filter syringe (Cameo $3 \mathrm{~N}$ syringe nylon filter, Micron Separation). An injection volume of $100 \mu \mathrm{l}$ of this purified extract was used to determine the periphyton lipophilic pigment composition by HPLC. Pigments were separated on a $4.6 \times$ $250 \mathrm{~mm}$ column (Waters Spherisorb ODS5, $25 \mu \mathrm{m}$ ). Each pigment was identified by its retention time and absorption spectrum using DAD according to SCOR (Jeffrey et al. 1997).

Chlorophyll a (chl a) was selected as an indicator of the total periphyton biomass (Bonin \& Travers 1992). Biomasses are given as $\mu \mathrm{g} \mathrm{chl} \mathrm{a} \mathrm{cm}^{-2}$. We used a quantitative calculation model based on published ratios for monocultures (Wilhelm et al. 1991, Dorigo et al. 2003). The following ratio was used in calculations of the percentage contribution of each algal group (a.g.):

$$
\% \text { a.g. }=\frac{\left(\% A_{\mathrm{dp}} \times 100\right)}{\left(\% A_{\mathrm{chl} a} \times r_{\mathrm{w}}\right)}
$$

where $A$ is the area of the peak, dp is the diagnostic pigment and $r_{\mathrm{W}}$ is the published ratio for monocultures. A table was constructed (with samples as rows and pigments as columns) by taking into account the relative abundance of each pigment in a given sample (expressed as a percentage of the sum of the area of all pigments in a sample). The matrix was used for correspondence analysis using the ADE-4 software package. In addition, the total number of pigments and the total number of degraded pigments per sample were counted.

PICT measurements. We tested the sensitivity of periphyton to the herbicide Diuron (regularly detected in the downstream sections of the River Morcille) in both water and biofilm samples (Gouy \& Nivon 2006, Montuelle et al. 2006). This herbicide is currently found in the majority of French surface waters (IFEN 2006). Diuron is frequently cited as a model molecule for Photosystem II (PSII) inhibition (Roy \& Legendre 1979, Krause \& Weis 1988). According to the co-tolerance hypothesis, biofilm Diuron tolerance may inform us not only about past contamination pressure exerted by this herbicide, but also about tolerance towards all PSII inhibitors. Using ${ }^{14} \mathrm{C}$ photosynthetic-assimilation as an endpoint, we monitored the effects on periphyton of semilogarithmic increases in concentrations of Diuron (Guasch \& Sabater 1998). Briefly, a Diuron stock solution of $100 \mu \mathrm{M}$ (MW 233) was dissolved in water and stored at $-20^{\circ} \mathrm{C}$ prior to dilution in the test vessels. Diuron was a high grade pesticide standard (Sigma, 99.5\% purity). A semi-logarithmic concentration series was freshly prepared with a multiplication factor of $10^{0.5}$ by serial dilution of the stock solution with $0.2 \mu \mathrm{m}$ filtered river water. Final test concentrations in the test vessels ranged from 0 to $10 \mu \mathrm{M}$ (1 blank and 9 increasing concentrations of Diuron). Ten homogeneous glass discs were selected on each Plexiglas plate for the spring experiment; for logistical reasons, 10 homogeneous glass discs were selected on the 3 Plexiglas plates of each sampling area for the winter experiment. Measurements of photosynthesis activity by ${ }^{14} \mathrm{C}$ incorporation were according to Dorigo \& Leboulanger (2001). Data were fitted to a sigmoid dose-response model using the least squares method. The model was used to determine photosynthetic EC50 values for each sampling area and period.

\section{RESULTS}

\section{Physico-chemical data}

Temperature values ranged from 9.5 to $11.8^{\circ} \mathrm{C}$ in spring, increasing slightly in the downstream direction, and from 2.4 to $3.3^{\circ} \mathrm{C}$ in winter, also decreasing in the downstream direction (Table 2). Water depths above the Plexiglas plates were similar in both winter and spring, increasing in the downstream direction, and varying between 8 and $15 \mathrm{~cm}$. Light conditions were mainly determined by the riparian vegetation and to a minor extent by the water depth. Photon irradiance ranged from 51.93 to $88.03 \mu \mathrm{mol} \mathrm{m}^{-2} \mathrm{~s}^{-1}$ in spring and from 81.57 to $125.15 \mu \mathrm{mol} \mathrm{m}^{-2} \mathrm{~s}^{-1}$ in winter. Water current ranged from 0.07 to $0.16 \mathrm{~m} \mathrm{~s}^{-1}$ in spring and from 0.26 and $0.38 \mathrm{~m} \mathrm{~s}^{-1}$ in winter. All chemical parameters, except $\mathrm{pH}$ and $\mathrm{NO}_{3}{ }^{-}$, increased gradually in the downstream direction in spring and winter; $\mathrm{pH}$ values were relatively constant along the river and ranged between 7.1 (winter) and 7.7 (spring); $\mathrm{NO}_{3}{ }^{-}$ values were highest for Area $\mathrm{V}$, the intermediate sampling area (Table 2). The upstream section of the River 
Table 2. Means (SD in parentheses) of the median temperature $\left(T,{ }^{\circ} \mathrm{C}\right)$, water height $\left(W_{\mathrm{h}}, \mathrm{Cm}\right)$, photon irradiance $\left(I_{1} \mu \mathrm{mol} \mathrm{m}^{-2} \mathrm{~s}^{-1}\right)$ and current speed $\left(W_{\mathrm{c}}, \mathrm{m} \mathrm{s}^{-1}\right)$ recorded weekly at 3 sampling sites in each sampling area (J: St. Joseph, V: Versauds, E: St. Ennemond). The median of each selected chemical parameter $\left(\mathrm{pH}_{;}\right.$Cond.: conductivity $\left[\mu \mathrm{Cm}^{-1}\right] ; \mathrm{DOC}\left[\mathrm{mg} \mathrm{l}^{-1}\right] ; \mathrm{NO}_{2}^{-}\left[\mathrm{mg} \mathrm{l}^{-1}\right]$; $\mathrm{NO}_{3}{ }^{-}\left[\mathrm{mg} \mathrm{l}^{-1}\right] ; \mathrm{NH}_{4}{ }^{+}\left[\mathrm{mg} \mathrm{l}^{-1}\right]$ and $\mathrm{PO}_{4}{ }^{3-}\left[\mathrm{mg} \mathrm{l}^{-1}\right]$ ) was obtained from weekly water samples from each sampling area in spring and winter

\begin{tabular}{|c|c|c|c|c|c|c|c|c|c|c|c|}
\hline Sampling area & $T$ & $W_{\mathrm{h}}$ & $I$ & $W_{\mathrm{c}}$ & $\mathrm{pH}$ & Cond. & DOC & $\mathrm{NO}_{2}^{-}$ & $\mathrm{NO}_{3}^{-}$ & $\mathrm{NH}_{4}^{+}$ & $\mathrm{PO}_{4}{ }^{3-}$ \\
\hline \multicolumn{12}{|l|}{ Spring } \\
\hline $\mathrm{J}$ & $9.5(0.34)$ & $8.5(6.81)$ & $88.03(90.54)$ & $0.16(0.06)$ & 7.7 & 135 & 2.05 & 0.02 & 7.4 & 0.04 & 0.1 \\
\hline $\mathrm{V}$ & $10.6(0)$ & $11(3.66)$ & $51.93(22.19)$ & $0.09(0.04)$ & 7.45 & 175 & 2.35 & 0.03 & 8 & 0.04 & 0.28 \\
\hline $\mathrm{E}$ & $11.8(0)$ & $14.8(3.11)$ & $87.08(44.14)$ & $0.07(0.04)$ & 7.5 & 200 & 3.25 & 0.07 & 6.1 & 0.08 & 0.36 \\
\hline \multicolumn{12}{|l|}{ Winter } \\
\hline $\mathrm{J}$ & $3.3(0.34)$ & $8(3.61)$ & $101.96(69.96)$ & $0.26(0.06)$ & 7.1 & 145 & 1.75 & 0.02 & 8.6 & 0.04 & 0.09 \\
\hline V & $2.4(0)$ & $12.3(2.52)$ & $125.15(38.91)$ & $0.33(0.04)$ & 7.1 & 190 & 2.35 & 0.02 & 11 & 0.05 & 0.19 \\
\hline E & $2.4(0)$ & $14.8(1.53)$ & $81.57(23.01)$ & $0.38(0.1)$ & 7.3 & 220 & 3.2 & 0.04 & 9.65 & 0.09 & 0.29 \\
\hline
\end{tabular}

Table 3. Pesticide contamination levels in the River Morcille measured at the end of the biofilm sampling period in each sampling area (J: St. Joseph; V: Versauds; E: St. Ennemond) and sampling season (values in bold refer to spring season, while non-bolded values refer to winter season); 333 molecules were searched for. All concentrations are $\mu \mathrm{g} \mathrm{l}^{-1}$; -: below detection limit

\begin{tabular}{|c|c|c|c|}
\hline Pesticide & $\mathrm{J}$ & $\mathrm{V}$ & $\mathrm{E}$ \\
\hline \multirow[t]{2}{*}{ 1(3'4 dichlorophenyl)3 methylurea ${ }^{a, b}$} & - & - & 0.2 \\
\hline & - & - & - \\
\hline \multirow[t]{2}{*}{ Atrazine deisopropyl ${ }^{a, b}$} & - & - & - \\
\hline & - & - & 0.01 \\
\hline \multirow[t]{2}{*}{ Azoxystrobin $^{c}$} & - & 0.13 & 0.05 \\
\hline & - & - & - \\
\hline \multirow[t]{2}{*}{ Dichlorobenzamide $2.6^{\mathrm{a}}$} & - & 0.2 & 0.17 \\
\hline & 0.02 & 0.03 & 0.28 \\
\hline \multirow[t]{2}{*}{ Diuron $^{\mathrm{a}, \mathrm{b}}$} & - & 0.09 & 0.43 \\
\hline & 0.01 & 0.01 & 0.04 \\
\hline \multirow[t]{2}{*}{ Monuron $^{\mathrm{a}, \mathrm{b}}$} & - & 0.86 & 0.02 \\
\hline & - & - & - \\
\hline \multirow[t]{2}{*}{ Myclobutanyl $^{\mathrm{a}, \mathrm{b}}$} & - & - & 0.06 \\
\hline & - & - & - \\
\hline \multirow[t]{2}{*}{ Norflurazon $^{\mathrm{a}}$} & - & 0.38 & 0.6 \\
\hline & 0.07 & 0.1 & 0.28 \\
\hline \multirow[t]{2}{*}{ desmethyl Norflurazon ${ }^{a}$} & 0.07 & 0.86 & 0.93 \\
\hline & 0.52 & 0.84 & 3.1 \\
\hline \multirow[t]{2}{*}{ Oxadixyl $l^{c}$} & - & 0.18 & 0.32 \\
\hline & 0.02 & 0.03 & 0.14 \\
\hline \multirow[t]{2}{*}{ Procymidone $^{c}$} & - & 0.11 & 0.1 \\
\hline & - & - & - \\
\hline \multirow[t]{2}{*}{ Simazine $^{\mathrm{a}, \mathrm{b}}$} & - & 0.02 & 0.03 \\
\hline & 0.01 & - & 0.02 \\
\hline \multirow[t]{2}{*}{ Tebuconazole $^{c}$} & - & - & 0.08 \\
\hline & - & - & - \\
\hline \multirow[t]{2}{*}{ Terbumeton $^{\mathrm{a}, \mathrm{b}}$} & - & 0.02 & 0.02 \\
\hline & - & - & 0.02 \\
\hline \multirow[t]{2}{*}{ Terbutylazine $e^{a, b}$} & - & 0.14 & 0.21 \\
\hline & - & 0.01 & 0.03 \\
\hline \multirow[t]{2}{*}{ Terbutylazine desethyl ${ }^{a}$} & - & 0.11 & 0.08 \\
\hline & 0.03 & 0.04 & 0.08 \\
\hline
\end{tabular}

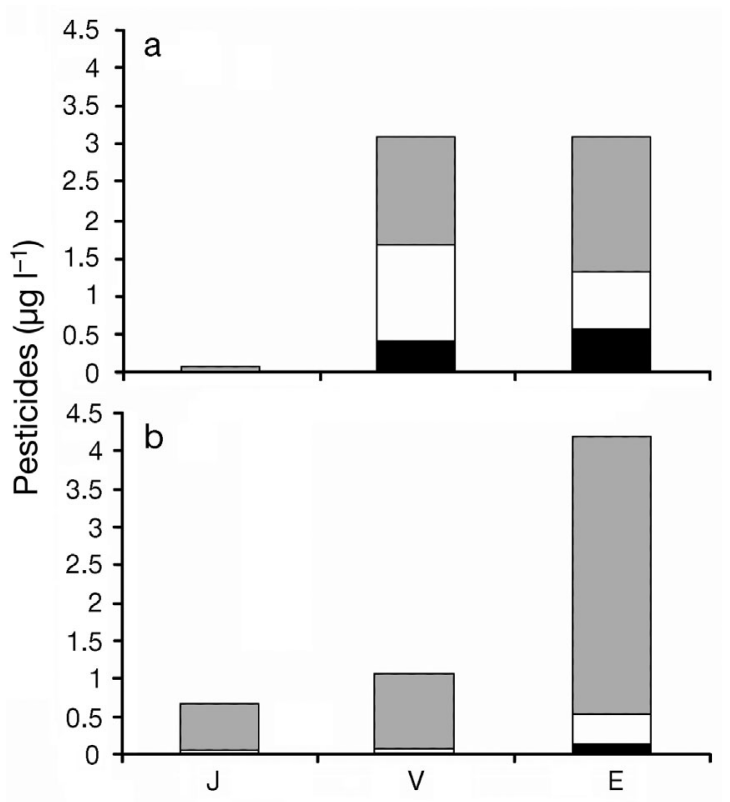

Fig. 2. Contamination by fungicides (black box), PSII inhibitors (white box) and herbicides other than PSII inhibitors (grey box) in the River Morcille in 3 sampling areas (J: St. Joseph; V: Versauds; E: St. Ennemond) in (a) spring and (b) winter

Morcille is oligotrophic $\left(\mathrm{PO}_{4}{ }^{3-}\right.$ values ranging between 0.09 and $0.1 \mathrm{mg} \mathrm{l}^{-1}$ ) and the downstream sections are oligomesotrophic $\left(\mathrm{PO}_{4}{ }^{3-}\right.$ values ranging between 0.19 and $0.36 \mathrm{mg} \mathrm{l}^{-1}$ ).

At the end of each experimental period, we searched for 330 toxic compounds, finding and quantifying 15 pesticides and 10 pesticide degradation products in both seasons in at least one sampling area (Table 3). Toxic compounds were divided into 3 groups, fungicides, PSII inhibitors and 'other herbicides', the latter having deleterious effects on plants other than the PSII inhibition (Fig. 2). Among the herbicides, 2 molecules were found in almost all water samples and sometimes at high concentration, i.e. Norflurazon $\left(\leq 0.6 \mu \mathrm{g} \mathrm{l}^{-1}\right)$ and 


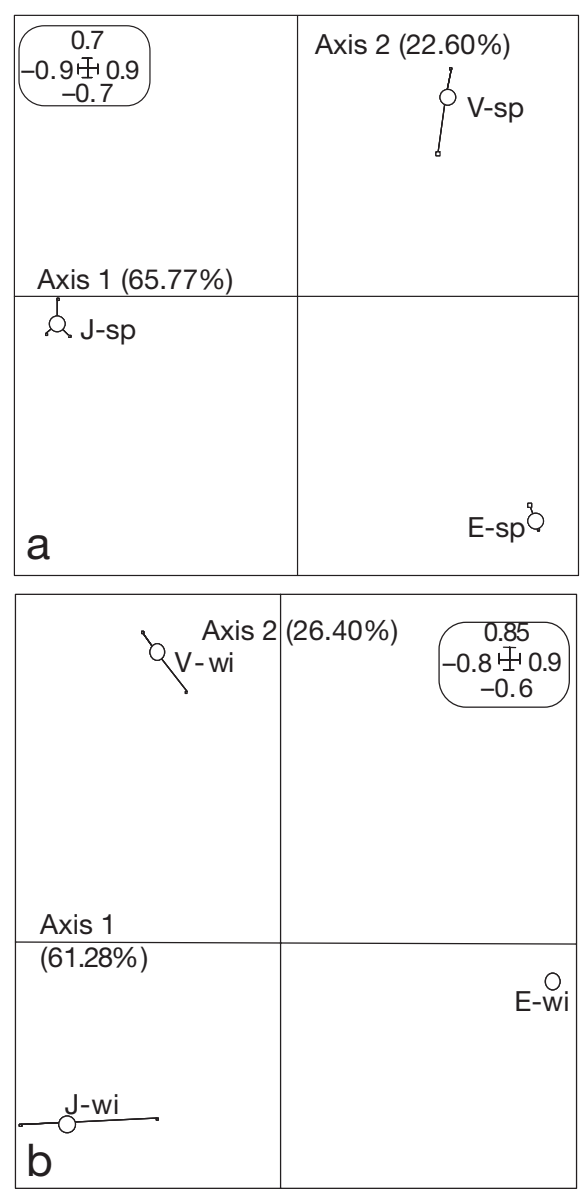

Fig. 3. Correspondence analysis of prokaryotic DGGE bands for each sampling site and area (J: St. Joseph; V: Versauds; E: St. Ennemond) in (a) spring (sp) and (b) winter (wi). The rounded-cornered rectangles express relative size of each part of the 2 axes; lines extending from the circles represent center of gravity of the replicates $(O)$ and show measures of dispersion

its degradation product, desmethyl Norflurazon $\left(\leq 0.93 \mu \mathrm{g} \mathrm{l}^{-1}\right)$. Among the fungicides, Oxadixyl $\left(\leq 0.32{\mu \mathrm{g}^{-1}}^{-}\right)$was the most prevalent. Total concentration of pesticides increased, as expected, in the downstream direction in both seasons. In spring, all 3 toxin categories were present at Areas V and E (Fig. 2a). In winter, Area $\mathrm{E}$ was the most contaminated (4 to 6 times higher concentrations than other areas), and most of its toxins were in the category 'other herbicides' (Fig. 2b).

\section{DGGE analyses}

\section{Bacterial community structure}

Among the 9 biofilm samples collected in spring and winter, 27 and 23 different bands were detected, respectively. The number of bands detected in each sam- pling area varied from 10 to 15 in winter $($ mean $=13$ ) and from 10 to 21 in spring (mean $=15$ ); the number of spring bands decreased significantly in the downstream direction. Correspondence analysis was applied to the band presence/absence data for samples in spring and winter (Fig. 3). The first 2 axes of each analysis accounted for $88 \%$ of the variability in both spring and winter. In spring (Fig. 3a) the first axis separated the pristine Area $J$ from the others, whereas the second axis separated Area V from Area E. In winter (Fig. 3b), Areas J and V were very close and separated from Area E. In all these projections, there was very low variability between the 3 plates in each sampling area.

\section{Eukaryotic community structure}

In the 9 biofilm samples collected in spring and winter, 40 and 45 different bands were detected, respectively. The number of bands detected in each sampling area varied from 19 to 33 in spring (mean = 25, lowest in Area J) and from 11 to 28 (mean = 19) in winter. Correspondence analysis was applied to the band presence/absence data for spring and winter samples (Fig. 4). The first 2 axes of each correspondence analysis accounted for 96 and $67 \%$ of the variability in spring and winter, respectively. In spring (Fig. 4a), the first axis separates the pristine Area $\mathrm{J}$ from Areas $\mathrm{V}$ and $E$, and the second axis separates Areas $V$ and E. In winter (Fig. 4b), Areas J and V are very close and separated from Area $\mathrm{E}$ on the first axis. In winter, there was a very high dispersion between the 3 plates from Area E.

\section{HPLC pigment analyses}

Diagnostic pigment signatures indicated the presence of diatoms, green algae and cyanobacteria in biofilms, and relative percentages of these 3 groups were calculated (Table 4). Diatoms (identified by the presence of fucoxanthin) appeared to dominate all samples and were particularly abundant in spring in Area E (87\% of total biomass). Green algae were only present in spring at Areas $\mathrm{J}$ and $\mathrm{V}$, and cyanobacteria were relatively abundant only at Areas $\mathrm{V}$ and $\mathrm{E}$ in spring. The most abundant pigments throughout the 2 seasons ( $\geq 1 \%$ in at least one sampling site) were chl $a_{\text {, }}$ fucoxanthin, chl $c$, violaxanthin, zeaxanthin, diadinoxanthin, beta-carotene and lutein. A total of up to 20 and 18 pigments were identified in spring and in winter, respectively, approximately one third of which were degraded pigments. In all sampling areas, chl a ranged on average from 0.41 to $2.08 \mu \mathrm{g} \mathrm{cm}^{-2}$, accounting for $55 \%$ of the total pigment in all sampling areas. 

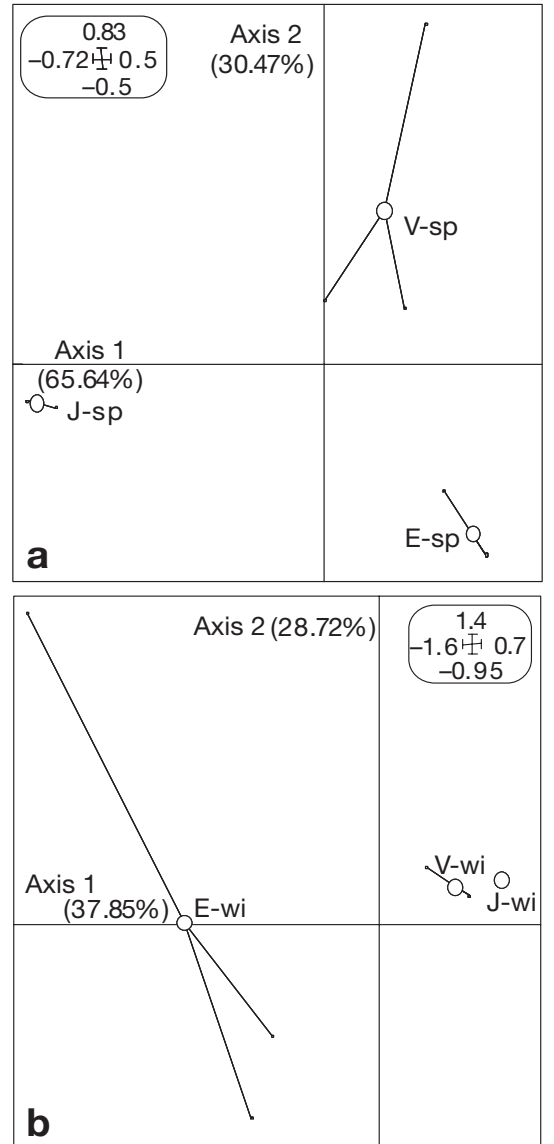

Fig. 4. Correspondence analysis of eukaryotic DGGE bands for each sampling site and area (J: St. Joseph; V: Versauds; E: St. Ennemond) in (a) spring (sp) and (b) winter (wi). See Fig. 3 for further details
Both in spring and in winter, chl a was lowest in Area E.

Through correspondence analysis, taking into account the relative percentage of pigments detected in all sampling sites in winter and in spring, we obtained a graphical representation of the evolution of microalgal community pigment structure (Fig. 5). By projection in the plane defined by the first 2 axes, there was a clear separation between spring and winter samples. The second axis allowed differentiation of Area J spring samples from the other spring samples. Area E winter samples were clearly separated from other winter samples.

\section{EC50 values}

Diuron EC50 values were estimated in order to evaluate natural tolerance of the communities to this pollutant. EC50 values increased in the downstream direction in both seasons, ranging from 19.71 to 42.23 and from 9.17 to $50.66 \mu$ Diuron $\mathrm{l}^{-1}$ in spring and winter, respectively (Fig. 6). Except for Area E, EC50 values were higher in spring than in winter. Within each season, lowest EC50 values (thus lowest tolerance to Diuron) were recorded for the pristine Area J.

\section{DISCUSSION}

Our aim was to evaluate in the field the impact of pesticide pollution on biofilms along a river subjected

Table 4. Means (SD in parentheses) of pigment characteristics for biofilm samples from each sampling area (J: St. Joseph; V: Versauds; E: St. Ennemond) on the River Morcille determined by HPLC on lipophilic fraction. nd: not detected; chl $c$ : chlorophyll $c_{i}$ fucox: fucoxanthin; viola: violaxanthin; ddx: diadinoxanthin; lut: lutein; zea: zeaxanthin; beta-c: beta-carotene; chl a: chlorophyll $a_{i}$ D: diatoms; G: green algae; C: cyanobacteria; tP: number of total pigments (degraded and non-degraded pigments); dP: number of degraded pigments

\begin{tabular}{|c|c|c|c|c|c|c|c|c|c|c|c|c|c|c|}
\hline \multirow{2}{*}{$\begin{array}{l}\text { Sampling } \\
\text { area }\end{array}$} & \multirow{2}{*}{$\begin{array}{c}\operatorname{chl~} a \\
\left(\mu \mathrm{cm}^{-2}\right)\end{array}$} & \multicolumn{8}{|c|}{ Contribution to total pigment (\%) } & \multicolumn{3}{|c|}{ Total biomass (\%) } & \multirow[t]{2}{*}{ tP } & \multirow[t]{2}{*}{$\mathrm{dP}$} \\
\hline & & $\operatorname{chl} C$ & fucox & viola & $\mathrm{ddx}$ & lut & zea & beta-c & chl $a$ & D & G & $\mathrm{C}$ & & \\
\hline \multicolumn{15}{|l|}{ Spring } \\
\hline $\mathrm{J}$ & $\begin{array}{c}1.54 \\
(0.06)\end{array}$ & $\begin{array}{l}12.21 \\
(3.08)\end{array}$ & $\begin{array}{l}20.74 \\
(3.66)\end{array}$ & $\begin{array}{c}1.2 \\
(0.48)\end{array}$ & $\begin{array}{c}1.77 \\
(0.32)\end{array}$ & $\begin{array}{c}0.12 \\
(0.21)\end{array}$ & $\begin{array}{c}2.01 \\
(0.42)\end{array}$ & $\begin{array}{c}2.18 \\
(0.99)\end{array}$ & $\begin{array}{l}59.44 \\
(5.40)\end{array}$ & $\begin{array}{l}37.50 \\
(9.39)\end{array}$ & $\begin{array}{l}29.25 \\
(7.51)\end{array}$ & $\begin{array}{l}1.27 \\
(2.2)\end{array}$ & $\begin{array}{l}14.67 \\
(1.53)\end{array}$ & $\begin{array}{c}4 \\
(1)\end{array}$ \\
\hline V & $\begin{array}{c}1.75 \\
(0.96)\end{array}$ & $\begin{array}{c}3.04 \\
(0.83)\end{array}$ & $\begin{array}{l}20.43 \\
(5.61)\end{array}$ & $\begin{array}{c}1.82 \\
(0.52)\end{array}$ & $\begin{array}{c}2.78 \\
(1.40)\end{array}$ & $\begin{array}{c}2.43 \\
(1.08)\end{array}$ & $\begin{array}{c}1.13 \\
(1.64)\end{array}$ & $\begin{array}{c}1.98 \\
(1.54)\end{array}$ & $\begin{array}{l}62.42 \\
(5.22)\end{array}$ & $\begin{array}{c}34.9 \\
(12.57)\end{array}$ & $\begin{array}{c}15.06 \\
(21.47)\end{array}$ & $\begin{array}{c}26.26 \\
(11.26)\end{array}$ & $\begin{array}{l}17.33 \\
(3.06)\end{array}$ & $\begin{array}{c}3.33 \\
(0.58)\end{array}$ \\
\hline E & $\begin{array}{c}0.8 \\
(0.23)\end{array}$ & $\begin{array}{c}4.75 \\
(0.47)\end{array}$ & $\begin{array}{l}38.28 \\
(3.55)\end{array}$ & $\begin{array}{c}1.40 \\
(0.44)\end{array}$ & $\begin{array}{c}5.11 \\
(1.37)\end{array}$ & $\begin{array}{c}1.69 \\
(0.56)\end{array}$ & nd & $\begin{array}{c}0.20 \\
(0.27)\end{array}$ & $\begin{array}{l}46.98 \\
(4.34)\end{array}$ & $\begin{array}{c}87.06 \\
(15.63)\end{array}$ & nd & $\begin{array}{l}24.25 \\
(8.51)\end{array}$ & $\begin{array}{l}15.33 \\
(2.08)\end{array}$ & $\begin{array}{c}4 \\
(1)\end{array}$ \\
\hline \multicolumn{15}{|l|}{ Winter } \\
\hline $\mathrm{J}$ & $\begin{array}{c}2.08 \\
(0.77)\end{array}$ & $\begin{array}{l}14.36 \\
(4.19)\end{array}$ & $\begin{array}{l}24.53 \\
(1.68)\end{array}$ & $\begin{array}{c}5.71 \\
(1.44)\end{array}$ & $\begin{array}{c}0.43 \\
(0.54)\end{array}$ & nd & $\begin{array}{c}0.36 \\
(0.33)\end{array}$ & $\begin{array}{c}1.43 \\
(0.09)\end{array}$ & $\begin{array}{l}52.80 \\
(2.97)\end{array}$ & $\begin{array}{l}48.47 \\
(4.71)\end{array}$ & nd & $\begin{array}{c}5.83 \\
(5.33)\end{array}$ & $\begin{array}{l}14.33 \\
(4.04)\end{array}$ & $\begin{array}{c}4.67 \\
(1.53)\end{array}$ \\
\hline V & $\begin{array}{c}1.25 \\
(1.21)\end{array}$ & $\begin{array}{c}8.58 \\
(7.42)\end{array}$ & $\begin{array}{l}26.96 \\
(4.90)\end{array}$ & $\begin{array}{c}6.10 \\
(1.41)\end{array}$ & $\begin{array}{c}2.52 \\
(0.88)\end{array}$ & nd & $\begin{array}{c}0.15 \\
(0.27)\end{array}$ & $\begin{array}{c}1.65 \\
(0.45)\end{array}$ & $\begin{array}{l}53.02 \\
(3.15)\end{array}$ & $\begin{array}{l}53.97 \\
(7.45)\end{array}$ & nd & $\begin{array}{c}2.63 \\
(4.56)\end{array}$ & $\begin{array}{l}14.33 \\
(1.15)\end{array}$ & $\begin{array}{c}5.33 \\
(0.58)\end{array}$ \\
\hline E & $\begin{array}{c}0.41 \\
(0.14)\end{array}$ & nd & $\begin{array}{l}30.81 \\
(1.47)\end{array}$ & $\begin{array}{c}5.23 \\
(0.33)\end{array}$ & $\begin{array}{c}2.77 \\
(1.03)\end{array}$ & nd & nd & $\begin{array}{c}4.76 \\
(5.02)\end{array}$ & $\begin{array}{l}56.43 \\
(2.97)\end{array}$ & $\begin{array}{c}59.07 \\
(4.3)\end{array}$ & nd & nd & $\begin{array}{c}7.67 \\
(1.15)\end{array}$ & $\begin{array}{c}1.67 \\
(0.58)\end{array}$ \\
\hline
\end{tabular}




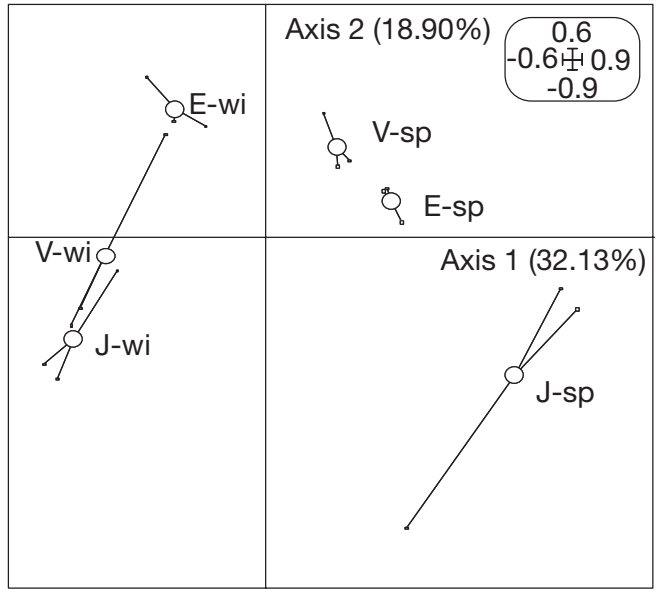

Fig. 5. Correspondence analysis of the \% contribution of each pigment in the 3 biofilm samples from 3 sampling areas (J: St. Joseph; V: Versauds; E: St. Ennemond) in spring (sp) and in winter (wi). See Fig. 3 for further details

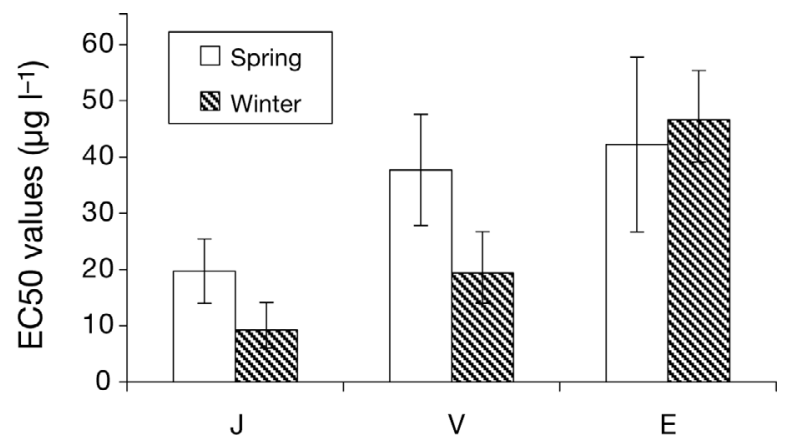

Fig. 6. Sensitivity (expressed as EC50 in $\mu g \mathrm{l}^{-1}$ estimated from primary productivity measurements on periphyton samples over a range of Diuron concentrations) from 3 sampling areas (J: St. Joseph; V: Versauds; E: St. Ennemond) on the River Morcille. Means \pm confidence limits $(n=3)$ of the EC50 values are shown. Confidence limits were calculated from standard deviations of replicate EC50s for spring, and from least square fitting residuals using SigmaPlot 10.0 for winter data (one EC50 value calculated from data fitted to the model sigmoid curve)

to increasing downstream contamination. Pesticide analyses of water confirmed previous findings on a marked contamination gradient along the River Morcille (Gouy \& Nivon 2006, Montuelle et al. 2006). The level of total pesticide contamination increased downstream (Table 3, Fig. 2). PSII inhibitors (mainly Monuron and Diuron) were particularly abundant in spring, whereas 'other herbicides' constituted the dominant group of pesticides in winter (mainly Norflurazon and its degradation product). On the Morcille watershed, herbicides are mainly applied from midMarch to mid-April, whereas fungicides are mainly applied from May to July (Gouy \& Nivon 2006). It is interesting that the total pesticide concentration remained relatively high even during the non-application period (autumn and winter), suggesting (1) that pesticides reach the river by leaching, diffusion and run-off, (2) that vineyard soils are strongly contaminated and (3) that compounds were persistent in this environment.

Except for the DGGE analysis of bacterial communities in spring (which demonstrated a decrease in taxonomic diversity in the downstream direction), our methods did not detect any loss in richness, but rather a change in community structure on the contamination gradient (shown by gel analysis and by correspondence analysis of gel data). HPLC analyses indicated that diatoms were the most abundant group in each sampling area, with green algae in the second rank. The predominance of diatoms within periphytic layers is very common in lotic systems (Stevenson \& Pan 1999). However, the proportion of diatoms was particularly high in Area E in spring, where high concentrations of pesticides were found. Pennate diatoms are known to be more tolerant of PSII inhibitors than other algae (Mølander \& Blanck 1992, Hoagland et al. 1993, Bérard et al. 1999). Cyanobacteria were only found in spring and at low abundances. These bacteria contain only small amounts of group-specific pigments, which cannot be detected when material for analysis is insufficiently concentrated. Low biomasses (0.41 to $2.08 \mu \mathrm{g}$ $\mathrm{cm}^{-2}$ ) may explain why the calculation method of Wilhelm et al. (1991) underestimated the total percentage contribution in most of the cases.

HPLC analyses performed on the photoautotrophic community and DGGE analyses performed on prokaryotic and eukaryotic communities both highlight changes in community structure down the river. Correspondence analysis of pigments separated (1) spring and winter communities, and (2) communities of less contaminated areas from those found in highly contaminated areas (Fig. 5). DGGE analyses revealed significant differentiation within prokaryotic and eukaryotic communities, separating those inhabiting less contaminated sampling areas from those collected in highly contaminated parts of the river (Figs. $3 \& 4$ ). Thus, the 2 methods used to assess structure of these communities (DGGE and HPLC) were concordant. The details of differentiation were as follows: in spring, the pristine Area J was markedly different from the other 2 sampling areas: (1) in the structure of the prokaryotic, eukaryotic and photoautotrophic communities and (2) in the level of pollution, which was much lower than at the other 2 sites. In winter, Areas J and V were more similar to Area $\mathrm{E}$ both in level of pollution and in microbial community structure.

In order to determine whether the structural changes we observed related to environmental contamination 
present in the river, and to make a risk assessment, we used the PICT concept develped by Blanck (2002) and applied by others (see Bérard et al. 2002, for a review). This concept proposes that the tolerance of a community to a toxicant is related to previous exposure of that community to the toxicant or to another toxicant belonging to the same toxicant family (neighbouring chemical composition and/or similar mode of action). This phenomenon of co-tolerance is well known and has been demonstrated for several contaminants (Mølander 1991, Blanck 2002, Bérard et al. 2003).

EC50 values that we measured were always higher than the concentrations of Diuron or total PSII inhibitor in the River Morcille (Table 3, Figs. 2 \& 6). Our EC50 values (9.17 to $50.66 \mathrm{\mu g} \mathrm{l}^{-1}$ ) fell within the range of other reports investigating sensitivity/tolerance of biofilms to Diuron (Mølander \& Blanck 1992). The most Diuron-sensitive communities were in pristine Area J in both seasons. The most Diuron-tolerant communities occurred in both seasons in Area E, the most severely contaminated. It is interesting that in winter, the intermediate Area $\mathrm{V}$ was similar to the pristine Area $\mathrm{J}$ in both contaminant concentration and Diuron sensitivity, while in spring and for both measures, Area V was more similar to Area E. There was strong correlation between EC50 values (Fig. 6) and percentages of vineyard area (Table 1$)\left(\mathrm{n}=6\right.$, Spearman's $r_{\mathrm{s}}=$ 0.96, p = 0.003), and between EC50 values (Fig. 6) and total pesticide concentration (Fig. 2) $(n=6$, Spearman's $\left.r_{\mathrm{s}}=0.93, \mathrm{p}=0.008\right)$. EC50 values obtained for the photoautotrophic community within biofilms varied with changing pesticide concentrations in river water and with structural changes in the biofilm communities. These results are congruent with the predictions of the PICT concept and suggest that pesticides likely constitute a selective pressure, at least on the photoautotrophic portion of the Morcille biofilms (Diuron is treated here as a model of pesticides that inhibit photosynthetic organisms in biofilms), producing changes in species composition and pesticide tolerance. These results are in accordance with previous studies (Dorigo et al. 2002, 2003) on Atrazine- and Isoproturon- (PSII inhibitors) contaminated rivers. Mølander \& Blanck (1992) reported changes in periphyton species composition and Diuron tolerance in marine microcosms exposed to different Diuron concentrations. Analogous results have been obtained for aquatic microalgal communities impacted by heavy metals (Barranguet et al. 2003).

Similar predictions may be made for the eukaryotes, since most are photoautotrophs, especially those on inorganic substrata (Tank \& Dodds 2003) (the communities we studied were attached to an inorganic glass substratum). Environmental parameters such as nutrients increase with elevated in situ pesticide concentra- tions (Montuelle et al. 2006), and nutrients are drivers of structural and functional changes in eukaryotic and photoautotrophic communities (deNicola et al. 2006). Within this framework of structure and function, application of the PICT concept allows us to attribute observed changes to pesticides, rather than to the direct nutrients effects. Nevertheless, we are unable to determine whether the structural changes in the prokaryotic communities studied were attributable to direct or indirect effects of pesticides, as opposed to other environmental factors. The relevant issues are as follows:

(1) We may exclude the influence of physical parameters on structural or functional changes (Romani \& Sabater 2001, Yannarell \& Triplett 2004) as we chose sampling sites to minimize variability in physical parameters (water current and light; authors' unpubl. data).

(2) Bacteria may be sensitive to changes in organic and inorganic nutrients (Schäfer et al. 2001). The DGGE approach has demonstrated differentiation of upstream and downstream bacterial communities in an anthropogenically impacted river section; differences were mainly attributable to variability in nitrogen and phosphorus concentrations (Lyautey et al. 2003). Similarly, changes in bacterial assemblages due to eutrophication occur in a reservoir in French Guiana (Dumestre et al. 2001).

(3) Bacteria may be unaffected, inhibited or stimulated by pesticides (Johnsen et al. 2001, Knapp et al. 2005). To date, major advances in this field have been achieved within the discipline of soil science; toxic contamination of soils is often dramatic. Biodegradation of pesticides has been demonstrated more frequently in soil (Martin-Laurent et al. 2006) than in aquatic environments (Schrap et al. 2000). As the contamination level found within the downstream sections of the River Morcille is likely to persist even during the apparently 'calm' period, there may be selection for resistant and/or pesticide-degrading microbial species. In an experimental approach with aquatic microcosms contaminated with $10 \mu \mathrm{g} \mathrm{l}^{-1}$ of Diuron, Pesce et al. (2006) detected the appearance and the persistence of several TTGE bands in Diuron-treated microcosms that were absent from reference microcosms; the bands may have corresponded to bacteria adapted or resistant to the contaminant.

(4) Bacteria may be sensitive to changes in the eukaryotic components of biofilms, particularly microalgae (Rier \& Stevenson 2002, Gao et al. 2004), without being directly affected by pesticides. Barranguet et al. (2003) observed structural changes in biofilm bacterial composition, indicating indirect effects; the impact of copper on microalgae translated into taxonomic changes in the prokayotic component, likely due to the close interdependence between autotrophs and heterotrophs in biofilms. 
(5) Finally, when performing DGGE gels on $16 \mathrm{~s}$ rRNA gene fragments, it is important to realize that there may be interference from eukaryote plastid DNA (van den Hoek et al. 1995, Cavalier-Smith 2000). Nevertheless, a phylogenetic analysis performed on $16 \mathrm{~S}$ rRNA gene fragments belonging to 2 different sets of river biofilm demonstrated that plastid contribution was $<25 \%$ of the operational taxonomic units analyzed (Lyautey et al. 2005b). Other pitfalls or limits of DGGE should be borne in mind (they are general to all DGGE analyses) (Wintzingerode et al. 1997).

In conclusion, our study revealed structural changes in bacterial, eukaryotic and phototrophic communities along the River Morcille. Tolerance to Diuron (a PSII inhibitor model molecule) increased with increasing concentrations of pesticides, with parallel structural changes in biofilm communities. These correlations suggest that structural and functional changes in the communities are likely driven by pesticides (especially herbicides). In the past $15 \mathrm{yr}$, the suitability of periphyton as an indicator of anthropogenic perturbation (particularly herbicide contamination; Guasch et al. 1998, Bruemmer et al. 2000) in aquatic ecosystems has been investigated in a variety of works (Blanco et al. 2004, Lewis et al. 2004, Sabater 2000). The periphyton comprises many taxonomic and functional components (prokaryotes, eukaryotes, photoautotrophs) that may react differently to external impacts, and we utilised techniques that allowed detection of group-specific pesticide effects. In future studies, it would be particularly relevant (1) to better assess the relative roles of nutrients and pesticides on structural changes in the prokaryotic community, and to untangle direct effects of pesticide exposure from indirect effects transmitted via microalgae associated with the prokaryote flora, and (2) to elucidate the impacts of fungicides within small rivers running through vineyard areas that are heavily contaminated by these compounds. While microalgae dominate inorganic substrata, fungi are the major biotic component of biofilms on allochthonous organic matter such as wood debris or leaf litter (Tank \& Dodds 2003) and, together with bacteria, they play a key role in organic matter decomposition.

Acknowledgements. The authors thank M. Lefranc for valuable work. We thank B. Motte and B. Volat for field sampling support and laboratory help. We thank the Water Chemistry Laboratory of the Cemagref station in Lyon for pesticide and nutrient analysis. We are grateful for the helpful criticism of an earlier version of the manuscript by the editor and 3 anonymous reviewers. D. Grivel is acknowledged for revising the English version of the manuscript. The project was (partially) funded by the Région Rhône-Alpes ('Appel d'offre Développement Durable, contract no. 05 01880201), by the ECCO- Ecodyn Research Program (Program Périphyteau 2003-2006) and was supported by the LTER Zone Atelier du Bassin du Rhône (ZABR).

\section{LITERATURE CITED}

AFNOR (Association Française de Normalisation) (1982) Essais des eaux: norme Française. NFT 90-023. AFNOR, La Plaine Saint-Denis

Barranguet C, Plans M, van der Grinten E, Sinke JJ, Admiraal W (2002) Development of photosynthetic biofilms affected by dissolved and sorbed copper in a eutrophic river. Environ Toxicol Chem 21:1955-1965

Barranguet C, van den Ende FP, Rutgers M, Breure AM, Greijdanus M, Sinke JJ, Admiraal W (2003) Copper-induced modifications of the trophic relations in riverine algalbacterial biofilms. Environ Toxicol Chem 22:1340-1349

Battin TJ, Kaplan LA, Newbold D, Hansen CME (2003) Contributions of microbial biofilms to ecosystem processes in stream mesocosms. Nature 426:439-442

Benoit M, Bonicelli B, Guichard L, Delorme R, Faloya V, Ruelle B (2005) Connaissance de l'utilisation des pesticides. In: Aubertot JN, Barbier JM, Carpentier A, Gril JJ and 5 others (eds) Pesticides, agriculture et environnement. Réduire l'utilisation des pesticides et en limiter les impacts environnementaux. Rapport d'expertise scientifique collective. INRA and Cemagref, Paris and Fresnes, p 1-59

Bérard A, Benninghoff C (2001) Pollution-induced community tolerance (PICT) and seasonal variations in the sensitivity of phytoplankton to atrazine in nanocosms. Chemosphere 45:427-437

Bérard A, Thomas P, Druart JC (1999) Seasonal variations in the sensitivity of Lake Geneva phytoplankton community structure to atrazine. Arch Hydrobiol 145:277-295

Bérard A, Dorigo U, Humbert JF, Leboulanger C, Seguin F (2002) La méthode PICT (Pollution-Induced Community Tolerance) appliquée aux communautés algales. Intérêt comme outil de diagnose et d'évaluation du risque écotoxicologique en milieu aquatique. Ann Limnol 38:247-261

Bérard A, Dorigo U, Mercier I, Becker van-Slooten KDG, Leboulanger C (2003) Comparison of the ecotoxicological impact of triazines Irgarol 1051 and atrazine on microalgal cultures and natural microalgal communities in Lake Geneva. Chemosphere 53:935-944

Blanck H (2002) A critical review of procedures and approaches used for assessing pollution-induced community tolerance (PICT) in biotic communities. Human Ecol Risk Assess 8:1003-1034

Blanco S, Ector, L, Bécares E (2004) Epiphytic diatoms as water quality indicators in Spanish shallow lakes. Vie Milieu 54:71-97

Boivin MEY, Massieux B, Breure AM, Greve GD, Rutgers M, Admiraal W (2006) Functional recovery of biofilm bacterial communities after copper exposure. Environ Pollut 140: 239-246

Bonin DJ, Travers M (1992) Examen critique des methods d'estimation de la biomasse et de l'activité des microorganisms dans les systèmes aquatiques. Mar Life 2:1-29

Brock TCM, Crum SJH, Deneer JW, Heimbach F, Roijackers RMM, Sinkeldam JA (2004) Comparing aquatic risk assessment methods for the photosynthesis-inhibiting herbicides metribuzin and metamitron. Environ Pollut 130:403-426

Bruemmer IHM, Fehr W, Wagner-Doebel I (2000) Biofilm community structure in polluted rivers: abundance of dominant phylogenetic groups over a complete annual cycle. Microbiology 66:3078-3082

Cattaneo A, Kerimian T, Roberge M, Marty J (1997) Periphyton distribution and abundance on substrata of different size along a gradient of stream trophy. Hydrobiologia 354: $101-110$ 
Cavalier-Smith T (2000) Membrane heredity and early chloroplast evolution. Trends Plant Sci 5:174-182

deNicola DM, de Eyto E, Wemaere A, Irvine K (2006) Periphyton response to nutrient addition in 3 lakes of different benthic productivity. J N Am Benthol Soc 25:616-631

Díez B, Pedrós-Alió C, Marsh TL, Massana R (2001a) Application of denaturing gradient gel electrophoresis (DGGE) to study the diversity of marine picoeukaryotic assemblages and comparison of DGGE with other molecular techniques. Appl Environ Microbiol 67:2942-2951

Díez B, Pedrós-Alió C, Massana R (2001b) Study of genetic diversity of eukaryotic picoplankton in different oceanic regions by small-subunit rRNA gene cloning and sequencing. Appl Environ Microbiol 67:2932-2941

Dorigo U, Leboulanger C (2001) A PAM fluorescence-based method for assessing the effects of photosystem II herbicides on freshwater periphyton. J Appl Phycol 13:509-515

Dorigo U, Bérard A, Humbert JF (2002) Comparison of eukaryotic phytobenthic community composition in a polluted river by partial 18S rRNA gene cloning and sequencing Microb Ecol 4:372-380

Dorigo U, Bourrain XAB, Leboulanger C (2003) Seasonal changes in river microalgae sensitivity to atrazine and isoproturon, along a contamination gradient. Sci Total Environ 318:101-114

Dorigo U, Fontvieille D, Humbert JF (2006) Spatial variability in the dynamic and the composition of the bacterioplankton community of the Lac du Bourget (France). FEMS Microbiol Ecol 58:109-119

Dumestre JF, Casamayor EO, Massana R, Pedrós-Alió C (2001) Changes in bacterial and archaeal assemblages in an equatorial river induced by the water eutrophication of Petit Saut dam reservoir (French Guiana). Aquat Microb Ecol 26:209-221

Gao X, Olapade OA, Kershner MW, Leff LG (2004) Algal-bacterial covariation in streams: a cross-stream comparison. Arch Hybrobiol 159:253-261

Gouy V, Nivon C (2006) Protection des eaux en Beaujolais viticole: caractérisation et suivi de la qualité des eaux sur le bassin versant de la Morcille sur la période 2001-2005, Cemagref, Rapport final d'étude. Cemagref, Fresnes

Guasch H, Sabater S (1998) Light history influences the sensitivity to atrazine in periphytic algae. J Phycol 34:233-241

Guasch H, Muñoz, Roxés N, Sabater S (1997) Changes in atrazine toxicity throughout succession of stream periphyton communities. J Appl Phycol 9:137-146

Guasch H, Ivorra N, Lehmann V, Paulsson M, Real M, Sabater $\mathrm{S}$ (1998) Community composition and sensitivity of periphyton to atrazine in flowing waters: the role of environmental factors. J Appl Phycol 10:203-213

Hoagland KD, Drenner RW, Smith DJ, Cross DR (1993) Freshwater community responses to mixtures of agricultural pesticides: effects of atrazine and bifenthrin. Environ Toxicol Chem 12:627-637

IFEN (Institut Français de l'Environment) (2006) Les pesticides dans les eaux - Données 2003-2004, Dossier de $l^{\prime} I F E N n^{\circ} 5$, Ministère de l'Ecologie et du Développement Durable. IFEN, Orleans

Jeffrey SW, Mantoura RFC, Wright SW (eds) (1997) Phytoplankton pigments in oceanography. UNESCO, Paris

Johnsen K, Jacobsen CS, Torsvik V, Sorensen J (2001) Pesticide effects on bacterial diversity in agricultural soils: a review. Biol Fertil Soils 33:443-453

Knapp CW, Caquet T, Hanson ML, Lagadic L, Graham DW (2005) Response of water column microbial communities to sudden exposure to deltamethrin in aquatic mesocosms. FEMS Microbiol Ecol 54:157-165
Krause GH, Weis E (1988) The photosynthetic apparatus and chlorophyll fluorescence: an introduction. In: Lichtenthaler HK (ed) Application of chlorophyll fluorescence. Kluwer, Dordrecht, p 3-11

Landry D, Dousset S, Andreux F (2004) Laboratory leaching studies of oryzalin and diuron through three undisturbed vineyard soil columns. Chemosphere 54:734-742

Lewis MA, Weber DL, Moore JC (2004) An evaluation of the use of colonized periphyton as an indicator of wastewater impact in near-coastal areas of the Gulf of Mexico. Arch Environ Contam Toxicol 43:11-18

Lyautey E, Teissier S, Charcosset JY, Rols JL, Garabetian F (2003) Bacterial diversity of epilithic biofilm assemblages of an anthropised river section, assessed by DGGE analysis of a 16 rDNA fragment. Aquat Microbiol Ecol 33: $217-224$

Lyautey E, Jackson CR, Cayrou J, Rols JL, Garabetian F (2005a) Bacterial community succession in natural river biofilm assemblages. Microb Ecol 50:589-601

Lyautey E, Lacoste B, Ten-Hage L, Rols JL, Garabetian F (2005b) Analysis of bacterial diversity in river biofilms using 16S rDNA PCR-DGGE: methodological settings and fingerprints interpretation. Water Res 39:380-388

Martin-Laurent F, Barres B, Wagschal I, Piutti S, Devers M, Soulas G, Philippot L (2006) Impact of the maize rhizosphere on the structure, the diversity and the gene composition of cultivable atrazine-degrading communities. Plant Soil 282:99-115

Massana R, Murray AE, Preston CM, DeLong EF (1997) Vertical distribution and phylogenetic characterization of marine planktonic Archaea in the Santa Barbara Channel. Appl Environ Microbiol 63:50-56

Mølander S (1991) Detection, validity and specificity of Pollution-Induced Community Tolerance (PICT). PhD dissertation, University of Göteborg

Mølander S, Blanck H (1992) Detection of pollution-induced community tolerance (PICT) in marine periphyton communities established under diuron exposure. Aquat Toxicol 22:129-144

Montuelle et al. (2006) Evaluation de gains biologique et écologique associés à une réduction d'intrants polluants en milieu aquatique, Rapport final Cemagref-CPER 2003-2006, Région Rhône Alpes. Cemagref, Fresnes

Pesce S, Fajon C, Bardot C, Bonnemoy F, Portelli C, Bohatier $\mathrm{J}$ (2006) Effects of the phenylurea herbicide diuron on natural riverine microbial communities in an experimental study. Aquat Toxicol 78:303-314

Rier ST, Stevenson RJ (2002) Effects of light, dissolved organic carbon, and inorganic nutrients on the relationship between algae and heterotrophic bacteria in stream periphyton. Hydrobiologia 489:179-184

Romani AM, Sabater S (2001) Structure and activity of rock and sand biofilms in a Mediterranean stream. Ecology 82: 3232-3245

Romani AM, Guasch H, Munoz I, Ruana J, Vilalta E, Schwartz T, Emtlazi F, Sabater S (2004) Biofilm structure and function and possible implications for riverine DOC dynamics. Microb Ecol 47:316-328

Roy S, Legendre L (1979) DCMU-enhanced fluorescence as an index of photosynthetic activity in phytoplankton. Mar Biol 55:93-101

Sabater S (2000) Diatom communities are indicators of environmental stress in the Guadiamar river, S-W Spain, following a major mine tailings spill. J Appl Phycol 12: 113-124

Sabater S, Gregory SV, Sedell JR (1998) Community dynamics and metabolism of benthic algae colonizing 
wood and rock substrata in a forest stream. J Phycol 34: 561-567

Sabater S, Guasch H, Romani A, Munoz I (2002) The effect of biological factors on the efficiency of river biofilms in improving water quality. Hydrobiologia 469:149-156

Sabater S, Guasch H, Ricart M, Romaní A, Vidal G, Klünder C, Schmitt-Jansen M (2007) Monitoring the effect of chemicals on biological communities. The biofilm as an interface. Analyt Bioanalyt Chem 387:1425-1434

Schäfer H, Bernard L, Courties C, Lebaron P and 7 others (2001) Microbial community dynamics in Mediterranean nutrient-enriched seawater mesocosms: changes in the genetic diversity of bacterial populations. FEMS Microbiol Ecol 34:243-253

Schauer M, Massana R, Pedrós-Alió C (2000) Spatial differences in bacterioplankton composition along the Catalan coast (NW Mediterranean) assessed by molecular fingerprinting. FEMS Microbiol Ecol 33:51-59

Schmitt-Jansen M, Altenburger R (2005) Toxic effects of isoproturon on periphyton communities - a microcosm study. Estuar Coast Shelf Sci 62:539-545

Schrap SM, van den Heuvel H, van den Meulen J, Ruiter H, Parsons JR (2000) A chemostat system for investigating pesticide biodegradation in continuous mixed bacteria cultures originating from surface water. Chemosphere 40: 1389-1397

Sekar R, Venugopalan VP, Nandakumar K, Nair KVK, Rao VNR (2004) Early stages of biofilm succession in a lentic freshwater environment. Hydrobiologia 512:97-108

Stevenson RJ, Pan YP (1999) Assessing environmental conditions in rivers and streams with diatoms. In: Stoermer EF,

Editorial responsibility: Rutger de Wit, Montpellier, France
Smol JP (eds) The diatoms: applications for the environmental and earth sciences. Cambridge University Press, Cambridge, p 11-40

Tank JL, Dodds WK (2003) Nutrient limitation of epilithic and epixyclic biofilms in ten North American streams. Freshw Biol 48:1031-1049

van den Hoek C, Mann DG, Jahns HM (1995) Algae. An introduction to phycology. Cambridge University Press, Cambridge

Vu SH, Ishihara S, Watanabe K (2006) Exposure risk assessment and evaluation of the best management practice for controlling pesticide runoff from paddy fields. Part 1: paddy watershed monitoring. Pest Manag Sci 62: 1193-1206

Weston DP, You J, Lydy MJ (2004) Distribution and toxicity of sediment-associated pesticides in agriculture-dominated water bodies of California's Central Valley. Environ Sci Technol 38:2752-2759

Wilhelm C, Rudolph I, Renner W (1991) A quantitative method based on HPLC-aided pigment analysis to monitor structure and dynamics of the phytoplankton assemblage - a study from Lake Meerfelder Maar (Eifel, Germany). Arch Hydrobiol 123:21-35

Wintzingerode FV, Goebel UB, Stackebrandt E (1997) Determination of microbial diversity in environmental samples: pitfalls of PCR-based rRNA analysis. FEMS Microbiol Rev 21:213-229

Yannarell AC, Triplett EW (2004) Within- and between-lake variability in the composition of bacterioplankton communities: investigations using multiple spatial scales. Appl Environ Microbiol 70:214-223

Submitted: March 29, 2007; Accepted: August 21, 2007

Proofs received from author(s): November 30, 2007 